\title{
Spatial factors of white-tailed deer herbivory assessment in the central Appalachian Mountains
}

\author{
Andrew B. Kniowski • W. Mark Ford
}

Received: 15 June 2017 / Accepted: 16 March 2018 /Published online: 25 March 2018

(C) This is a U.S. Government work and not under copyright protection in the US; foreign copyright protection may apply 2018

\begin{abstract}
Because moderate to over-abundant whitetailed deer (Odocoileus virginianus) herbivory impacts biodiversity and can alter community function, ecological benchmarks of herbivory impact are needed to assess deer impacts. We evaluated spatial patterns of deer herbivory and their relation to herbivory assessment by evaluating woody vegetation along 20 transects at each of 30 sites spread across a wide range of deer herd densities and vegetative condition throughout the biodiverse Appalachian Mountains of Virginia, USA. Surprisingly, herbivory patterns and the availability of woody forage generally were unchanged among physiographic regions and land use diversity classes. However, some relationships between browsing pattern and vegetation varied with scale. The total quantity of vegetation browsed on a given site and at the transect scale were related positively to the availability of forage, as the proportion of stems browsed decreased as stem density increased. However, this was only true when all stems were considered equally. When stem densities by species were weighted for deer preference, the
\end{abstract}

\footnotetext{
A. B. Kniowski $(\bowtie)$

Department of Fish and Wildlife Conservation, Virginia Tech, Blacksburg, VA 24061, USA

e-mail: kniowski@vt.edu

W. M. Ford

U.S. Geological Survey, Virginia Cooperative Fish and Wildlife Research Unit, Virginia Tech, Blacksburg, VA 24061, USA
}

proportion of stems browsed had no relationship or increased with stem density. Compared to the value from all transects sampled, on average, the mean of $\geq$ 3 transects within a site was within 0.1 of the browsing ratio and stem densities were within 0.5 stems $\mathrm{m}^{-2}$. Our results suggest that one transect per square kilometer with a minimum of three transects may be sufficient for most browsing intensity survey requirements to assess herbivory impacts in the Appalachian region of Virginia. Still, inclusion of spatial factors to help partition variation of deer herbivory potentially may allow for improved precision and accuracy in the design of field herbivory impact assessment methods and improve their application across various landscape contexts.

Keywords Appalachian Plateau · Blue Ridge · Forage availability · Herbivory · Impact assessment . Odocoileus virginianus $\cdot$ Ridge and Valley . White-tailed deer

\section{Introduction}

Ungulates significantly modify ecosystem structure and biodiversity (Hobbs 1996; Rooney and Waller 2003; Royo et al. 2010a; Bressette et al. 2012). Deer (Cervidae) influence biodiversity in a variety of ways, including directly through herbivory, which changes growth rate, development, survival, and succession of plants and resulting community composition (Russell 
et al. 2001), and indirectly through a cascade of impacts to other organisms. For example, researchers have related impacts of deer to bird communities, small mammals, and invertebrates that respond to change in plant communities (reviewed by Côté et al. 2004). Further, through mechanical action (e.g., trampling and browsing), and fecal pellet deposition, deer can influence nutrient cycling and the soil environment (Hobbs 1996), leading to impacts on litter and below-ground processes and biota (Rearick et al. 2011).

Deer and other ungulates generally live within landscapes that are heterogeneous mosaics of vegetation types and conditions, land forms, and land uses (Urban et al. 1987). Ecologists have long had an interest in spatial patterns resulting from interactions between landscapes and ecological processes (Turner 1989). For example, many environmental factors of importance to plant communities (i.e., moisture, light, nutrients, and climate) correlate with topographic and geologic attributes of landscapes (Swanson et al. 1988; McNab 1993; Meilleur et al. 1994; Ford et al. 2000; Clinton 2003). White-tailed deer (Odocoileus virginianus) (hereafter deer) are the most common and widespread large herbivore in eastern North America. Deer selectively forage based on type and nutritional content of vegetation (Nixon et al. 1970; Vangilder et al. 1982; Berteaux et al. 1998; Dostaler et al. 2011). Furthermore, topographic, climatic, and other variables may influence, or restrict access by deer to landscape areas (Schmitz 1991; Rooney 1997; Comisky et al. 2005; Krueger and Peterson 2006; Chollet et al. 2013). Thus, deer herbivory may vary spatially in relation to landscape characteristics. Although research on deer herbivory has been substantial (Russell et al. 2001; Rooney and Waller 2003; Côté et al. 2004), most research has not evaluated underlying spatial factors (but see Augustine and Jordan 1998) or how the extent and pattern of observed herbivory impacts occur in landscapes broadly.

Because deer can cause substantial changes to biodiversity, efforts to include ecological benchmarks or measures of herbivory impact in deer population management have increased, particularly in light of real or perceived overabundance in the eastern USA (de Calesta and Stout 1997; Morellet et al. 2007; Tierney et al. 2009; McShea 2012). Nonetheless, how herbivory varies spatially across landscapes and among landscape scales typically is unknown to managers in most settings, particularly in the central Appalachians (Campbell et al. 2006). For example, managing deer populations within limits that permit function of a biologically diverse ecosystem has been an objective of the Virginia, USA, state-wide deer management plan (Virginia Department of Game and Inland Fisheries 2015). However, there are few data or established protocols describing the sampling effort required to measure herbivory impact, the spatial variability of deer herbivory, or the applicability of suggested ecological measures across the varied habitats, landscapes, and surficial geology of Virginia or elsewhere (Côté et al. 2004; N. Lafon, Virginia Department of Game and Inland Fisheries, personal communication).

The development of broad-scale herbivory impact assessment methods requires an understanding of how deer browsing intensity or other measures of herbivory vary in relation to habitat productivity, topographic configuration, and other spatial factors. Additionally, understanding the variation of deer herbivory in relation to spatial factors potentially may improve the precision and accuracy of field assessment methods across various landscape contexts. Therefore, using a spatially balanced, multi-scale study design, our objectives were to examine (1) the relationship of deer herbivory patterns to geographical and land use configuration, (2) spatial patterns of deer herbivory, and (3) the influence of sampling effort on browsing intensity and forage availability estimates across the central Appalachian Mountains of Virginia, USA. Deer maintain small homeranges (Campbell et al. 2004b) and herbivory impacts can be localized to widespread depending on herd density (Ford et al. 1993; Campbell et al. 2006). A priori, we hypothesized that various measures and characterizations of deer herbivory would vary across multiple spatial scales and that spatial patterns of herbivory would differ more among physiographic regions and habitat configurations than at local scales. Specifically, we hypothesized that sites with greater land use diversity would have greater spatial variation in herbivory intensity.

\section{Materials and methods}

\section{Study area}

Our study area was the central Appalachian Mountain region of western Virginia, USA, comprising the Blue Ridge, Valley and Ridge, and Appalachian Plateau physiographic regions. Though variable across the wide 
ranges of elevations (200-1700 m), aspects, terrain shape/sheltering, surficial geology, and past land use, the region primarily is forested and largely dominated by (Quercus spp.) oak-hickory (Carya spp.), oak-pine (Pinus spp.), or mesic cove hardwood types. Wider valley bottoms in the Ridge and Valley and Blue Ridge contain a mix of pastoral grazing lands and limited rowcrop agriculture, residences, and urbanized areas (Kniowski and Ford 2017). Other than earlysuccessional habitat derived from forest harvesting and regeneration, nonforested habitats in the Appalachian Plateau primarily are reclaimed coal-production surface mines (Oliphant et al. 2016). Deer densities also varied across the region from high $\left(>20 \mathrm{~km}^{2}\right)$ to low $\left(<2 \mathrm{~km}^{2}\right)$. Generally, deer abundance was greater on private land than public land, and numbers in the Appalachian Plateaus were significantly less than either the Valley and Ridge or Blue Ridge (Virginia Department of Game and Inland Fisheries 2015).

\section{Data collection}

We divided the study area into six sampling regions following the physiographic divisions of Fenneman (1938) within the Appalachian Mountains of Virginia: Appalachian Plateau, Blue Ridge Northern, Blue Ridge Southern, Valley and Ridge Tennessee, and Valley and Ridge Middle. We divided the Valley and Ridge Middle section into two study regions due to its size; the subdivision roughly followed the boundary of the Potomac and James River watersheds, which separate the upper and lower portions of the Shenandoah Valley (Fig. 1). We selected 30 sites, five sites within each of the six sampling regions, and sampled woody vegetation within forested areas along 20 transects at each site. We distributed sites across forest types and land use with forest and land use diversity metrics. We calculated a measure of local forest diversity by creating a $30 \times 30-\mathrm{m}$ grid where values were the sum of the number of forest types defined by the Northeastern Terrestrial Wildlife Habitat Classification (Gawler 2008) within a 1-km radius surrounding each grid cell. To improve comparability among regions, we reclassified forest types into the following groups prior to diversity calculations: floodplain, cove hardwood, mesic hardwood, oak-hickory, mixed pine-oak, pine, northern hardwood, and red spruce (Picea rubens)-Fraser fir (Abies fraseri). Based on the distribution of our derived cover types, we ranked locations with forest diversity values $\geq 4$ as high forest diversity, locations with a diversity value of 3 as moderate forest diversity, and areas with diversity values of $\leq 2$ as low forest diversity (Kniowski and Ford 2017).

Similarly, we used the National Land Cover Dataset (Fry et al. 2011) to calculate land use diversity by creating a $30 \times 30$-m grid where values were the number of different land use classes within a $1-\mathrm{km}$ radius surrounding each grid cell. Prior to the diversity calculation, we reclassified land use as water, residential, urban, forest, grassland, pasture, and row-crop. We ranked areas with land use diversity values of $\geq 6$ as high, 4 or 5 as moderate, and areas $\leq 3$ as low land use diversity. We categorized possible assessment sites within each region based on forest type and land use diversity values, selecting one site with each of the following combinations of forest and land use diversity: high forest, high land use; high forest, low land use; low forest, high land use; low forest, low land use; and moderate land use, moderate forest diversity. We defined or limited site boundaries to a circular area $\leq 3 \mathrm{~km}^{2}$ to limit intra-site variation in browsing intensity due to potential variations in local deer population density. Therefore, our sites were approximately the home range size of an individual deer or female (doe) group in the region (Halls 1984; Tierson et al. 1985; Campbell et al. 2004a).

To provide a topographically representative and spatial balanced herbivory sample, within each site, we randomly selected 20 transect locations within forested areas using a generalized random tessellation-stratified design (Stevens and Olsen 2004). We stratified locations among 12 topographic and landform criteria representing combinations of slope, topographic exposure, and aspect (Swanson et al. 1988; McNab 1993; Meilleur et al. 1994; Ford et al. 2000; Clinton 2003) (Table 1). We defined slopes $\leq 20^{\circ}$ as low to moderate and those $>20^{\circ}$ as high. To assess topographic exposure, we used deviation from mean elevation (DEV) within a 500-m radius (De Reu et al. 2013) as the metric; positive values were higher than the surrounding mean elevation whereas negative values were lower than the surrounding mean (McNab 1993; Wilson and Gallant 2000; De Reu et al. 2013). We defined sheltered areas as those with a DEV $<-0.7$ and exposed areas as those with a DEV $>0.7$. We defined areas with DEV -0.7 to 0.7 as moderately exposed. We defined aspects $45^{\circ}-225^{\circ}$ as southeast and aspects $0^{\circ}-45^{\circ}$ or $225^{\circ}-359^{\circ}$ as northwest. Due to the long, linear alignment of most ridges in the region, these 


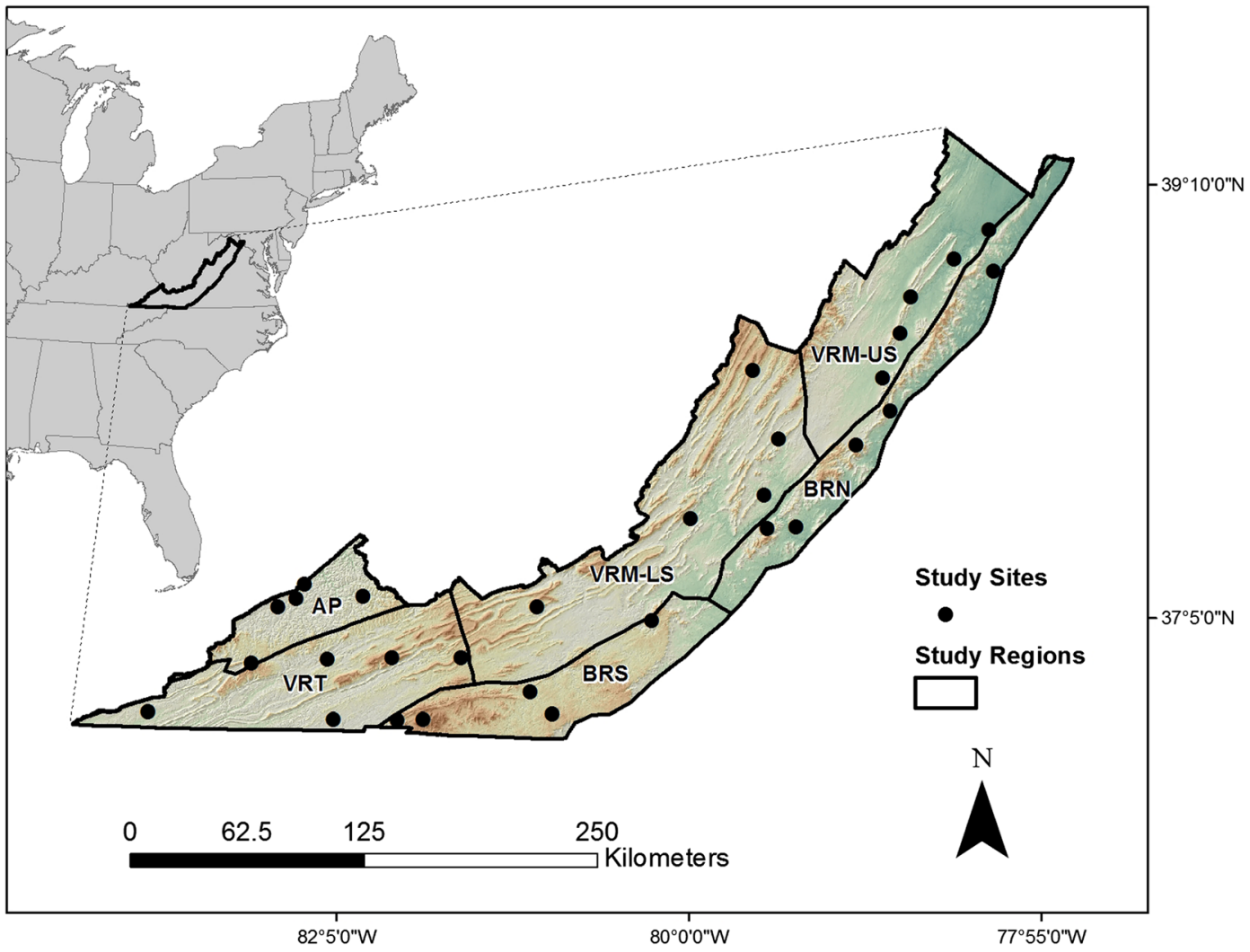

Fig. 1 White-tailed deer (Odocoileus virginianus) herbivory study regions and assessment sites in the central Appalachian Mountains of Virginia, USA, summer 2014. Regions include Appalachian Plateau (AP), Blue Ridge Northern (BRN), Blue

categories resulted in an aspect category for each dominant slope face. We oversampled random
Ridge Southern (BRS), Valley and Ridge Tennessee (VRT), Valley and Ridge Middle-Upper Shenandoah (VRM-US), and Valley and Ridge Middle-Lower Shenandoah (VRM-LS)

transect locations within each strata and maintaining at least $100 \mathrm{~m}$ between any two transects.
Table 1 Distribution of transects among topographic and landform criteria on white-tailed deer (Odocoileus virginianus) herbivory assessment sites in the central Appalachian Mountains of Virginia, USA, summer 2014
Strata criteria

$N$ transects

Low to moderate slope, exposed landform, SE aspect 2

Low to moderate slope, exposed landform, NW aspect

2

Low to moderate slope, sheltered landform, SE aspect

2

Low to moderate slope, sheltered landform, NW aspect

High slope, exposed landform, SE aspect

High slope, exposed landform, NW aspect

High slope, sheltered landform, SE aspect

High slope, sheltered landform, NW aspect

Low to moderate slope, average landform, SE aspect

Low to moderate slope, average landform, NW aspect

High slope, moderate landform, SE aspect

High slope, moderate landform, NW aspect 
To minimize elevation changes along transects, we oriented transects perpendicular to the grade or randomly in more flat locations. Along each transect at each location, we measured browsing intensity assessing woody vegetation within $1-\mathrm{m}^{2}$ subplots. We only examined and tallied woody stems because these leave persistent evidence of browsing unlike herbaceous plant growth (Morellet et al. 2001; Frerker et al. 2013). Across evenly distributed subplots (every $5 \mathrm{~m}$ ) along $50-\mathrm{m}$ transects (10 per transect), we counted and identified to species the total number of woody stems between 0.2 and $1.8 \mathrm{~m}$ in height within each subplot and recorded the number of stems browsed. We used rough versus clipped browse scar patterns to distinguish between that of deer versus the few instances when we observed browsing by cottontail rabbits (Sylvilagus spp.; Morellet et al. 2001).

\section{Data analysis}

We calculated two factors for each transect and site that were used as dependent variables in analyses. These included the number or density of woody stems (stems $\mathrm{m}^{-2}$ ) as an estimate of woody forage availability and the proportion of stems browsed by deer as a measure of deer browsing intensity (browsed stems/total number of stems; browsing ratio; Castleberry et al. 1999; Frerker et al. 2013). Because deer browse vegetation preferentially (Nixon et al. 1970; Vangilder et al. 1982; Dostaler et al. 2011), we calculated the browsing ratio of each vegetation species within the study area and by region to provide an estimate of deer forage preference. As vegetation changes from deer herbivory may be affected by browsing preference, we also calculated browsing ratios and stem densities weighted by deer forage preference. To do so, we multiplied the vegetation stem count by the studywide or regional browsing ratio for each vegetation species as provided by (Kniowski and Ford 2017) before calculation of the site or transect browsing ratio. This resulted in stems of plant species browsed frequently by deer being weighted more and those of vegetation species rarely browsed weighted less in stem count totals.

We assessed the relationships of deer herbivory patterns to geographical and land use configuration using linear mixed models with a random factor for site to account for our nested study design (Bolker et al. 2009; Zuur et al. 2009). We centered coordinates and square-root transformed scale, stem densities, and browsing ratios prior to the analyses. We tested for a difference in forage availability between study regions and between site habitat diversity categories using Kruskal-Wallis rank sum tests (Zar 1984). We used nonparametric tests for comparisons between regions and habitat diversity categories because data were not normally distributed. We evaluated the relationship between the quantity of forage browsed and forage availability and browsing ratio and forage availability using least square regression at the site scale and linear mixed models at the transect scale with site as a random factor. We logtransformed the number of stems, number of browsed stems, and number of available stems prior to analyses whereas the browsing ratio was square-root transformed. We used $R^{1}$ (Version 3.2.3, www.r-project. org, accessed 12 Dec 2015) to calculate statistical tests; packages "lme4" (Version 1.1-10, https://cran. r-project.org/package $=1$ me 4 , accessed 10 Oct 2015), "MuMIn" (Version 1.15.6, https://cran.r-project. org/package=MuMIn, accessed 12 Dec 2015), and "multcomp" (Version 1.4-1, https://cran.r-project. org/package $=$ multcomp, accessed 23 Aug 2015) were used in mixed model calculations. Pseudo $r$ squared values were calculated using the methods of Nakagawa and Schielzeth (2013).

To assess spatial patterns of deer herbivory, we estimated the variability of deer browsing intensity and the variability of foraging within each site by computing the coefficient of variation (CV; Zar 1984) of the browsing ratio, the weighted browsing ratio and number of stems and weighted stems, respectively, on transects. We compared site browsing intensity variation and vegetation density variation between study regions and between categories of site habitat diversity using Kruskal-Wallis rank sum tests. We used least square regression to evaluate the relationship between the variability of site browsing intensity and site forage availability, forage availability variation and site browsing ratio, browsing intensity variability and site browsing ratio, forage availability variation and site forage

\footnotetext{
${ }^{1}$ The use of any trade, product, or firm names does not imply endorsement by the US government.
} 
availability, and forage availability variation and browsing intensity variation.

To evaluate the extent of spatial relatedness of transect stem densities and browsing ratios, we calculated spatial autocorrelation and semi-variance statistics (Isaaks and Srivastava 1989; Fortin and Dale 2009). We used correlograms and semi-variograms to visualize how autocorrelation and semi-variance change with separation distance. We used package "ncf" (Version 1.1-6, https://cran.r-project. org/package $=$ ncf, accessed 7 Dec 2015) in $R$ to calculate autocorrelation statistics and assess correlation significance in $250 \mathrm{~m}$ distance class increments for separation distances $0-2 \mathrm{~km}$ and in $10 \mathrm{~km}$ distance class increments for separation distances 5-200 km. We used package "gstat" (Version 1.1-0, https://cran.r-project.org/package= gstat, accessed 18 Oct 2015) in $R$ to calculate and fit semi-variance models.

To evaluate the influence of sampling effort on site browsing ratio and stem density estimates, we used Monte Carlo simulations to mimic different amounts of sampling effort. For each simulation, we computed the absolute difference of the mean browsing ratio of a random subset of transects to the mean browsing ratio of all 20 transects on a site. We varied the number of transects in the subset from 2 to 19 to simulate different levels of sampling effort resulting in 18 simulations per site. We iterated each simulation 1000 times and recorded the standard deviation and mean difference for each level of sampling effort for all sites.

\section{Results and discussion}

Results

Overall, browsing ratios varied considerably among the 82 individual woody plant species and/or species groups as well as overall totals we documented study-wide. There were no significant differences between the number of woody stems on sites among regions or diversity categories $(P \geq 0.177)$. There was a positive relationship between the number of stems that were browsed on a site and the total number of stems available on the site $\left(r^{2}\right.$ adjusted $\left.=0.24, \beta=0.52, F_{1,28}=10.39, P=0.003\right)$. The relationship increased in strength for weighted stems $\left(r^{2}{ }_{\text {adjusted }}=0.42, \beta=0.61, F_{1,28}=21.99\right.$, $P<0.001 ; r_{\text {adjusted }}^{2}=0.64, \beta=0.87, F_{1}, 28=53.41$, $P<0.001$; for study-weighted and regionally weighted stem counts, respectively). There was a positive relationship between the number of browsed stems on individual transects and the total number of stems on transects (peudo- $r^{2}$ marginal $=$ $0.29, \beta=0.61,95 \% \mathrm{CI}=0.53$ to 0.69$)$. The relationship between the number of browsed stems on an individual transect and weighted stem counts was stronger than unweighted stems (peudo- $r_{\text {marginal }}^{2}=$ $0.50, \beta=0.98,95 \% \mathrm{CI}=0.90$ to 1.06 ; peudo- $r^{2}$ marginal $=0.56, \beta=0.98,95 \% \mathrm{CI}=0.90$ to 1.05 , for study-wide and regionally weighted stem counts, respectively). There was a negative relationship between the site browsing ratio and the total number of stems available on a site for unweighted stems $\left(r^{2}\right.$ adjusted $=0.24, F_{1,28}=10.24, P=0.003, \beta=-$ $0.13)$, but no relationship with weighted stem counts $(P \geq 0.108)$. There was a weak negative relationship between the browsing ratio on an individual transect and total number of stems on a transect (peudo- $r^{2}$ marginal $=0.01, \beta=-0.03,95 \% \mathrm{CI}-0.06$ to -0.01$)$. We observed a positive relationship between the transect browsing ratio and weighted stem counts (peudo$r_{\text {marginal }}^{2}=0.05, \beta=0.09,95 \% \mathrm{CI}=0.06$ to 0.13 ; peudo $-r_{\text {marginal }}^{2}=0.07, \beta=0.11,95 \% \mathrm{CI}=0.08$ to 0.14 ) for study-wide and regionally weighted stem counts, respectively.

There was no difference in intra-site browsing intensity variation among study regions or site diversity categories $(P \geq 0.15)$. Likewise, there was no difference in study-wide or regionally weighted intra-site browsing variation across study regions or site diversity categories $(P \geq 0.35)$. Intrasite stem density variation and intra-site weighted stem density variation also did not vary among study regions or site diversity categories $(P \geq$ $0.08)$. There was no relationship between site browsing variation and stem density $(P=0.68)$ or site stem density variation and site browsing ratio $(P=0.23)$. However, there was a negative relationship between site browsing variation and site browsing ratio $\left(r^{2}\right.$ adjusted $=0.50, F_{1}, 28=29.5$, $P<0.001)$ and site stem density variation and site stem density $\left(r^{2}\right.$ adjusted $=0.30, F_{1}, 28=14.2$, $P<0.001)$. That is, sites with high intensities of herbivory were browsed more uniformly and sites 


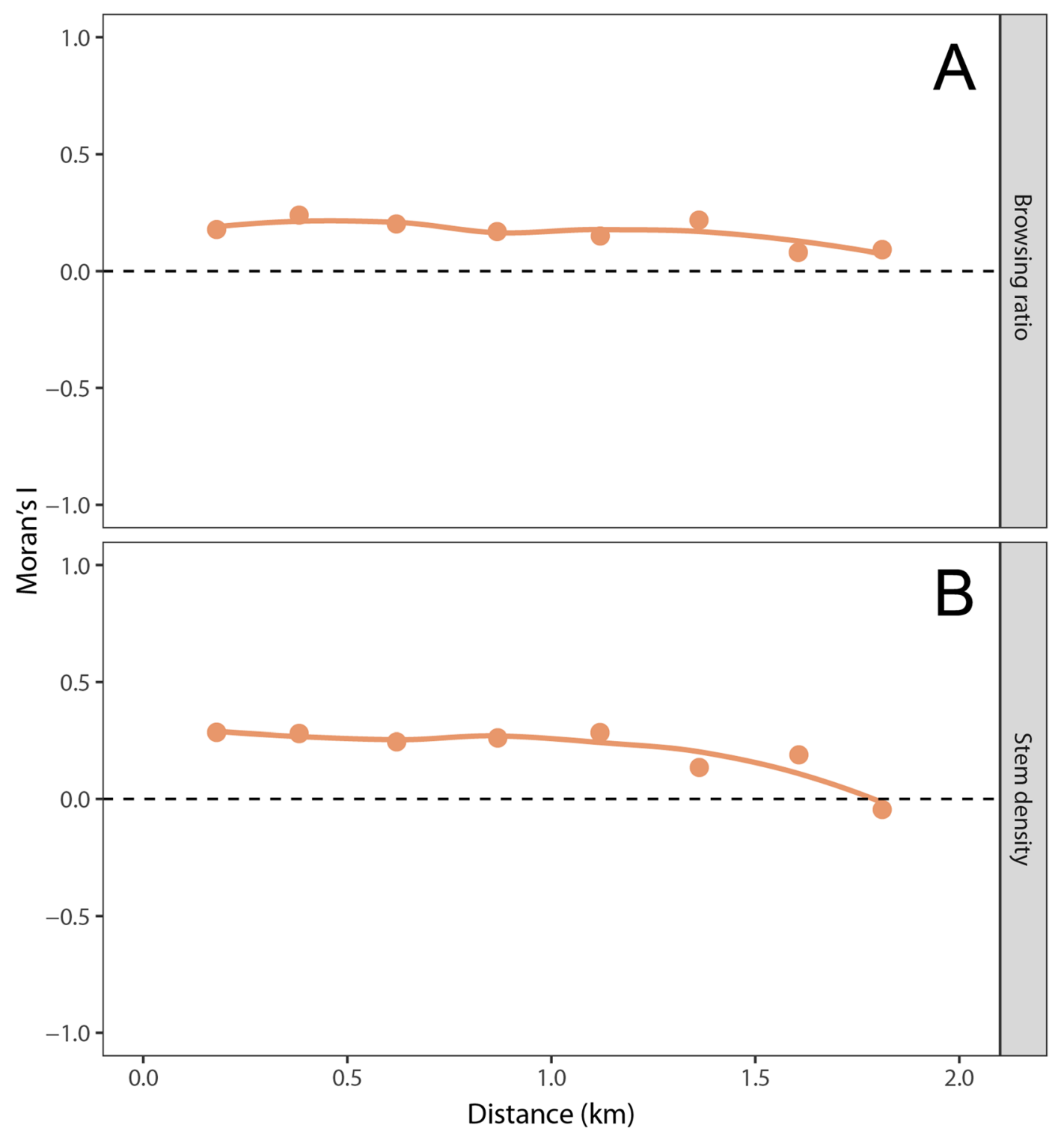

Fig. 2 Correlograms of woody vegetation browsing ratios (a) and stem densities (b) among transects at white-tailed deer (Odocoileus virginianus) herbivory assessment sites in the central

with higher densities of woody stems had less intra-site variation in woody stem density. There was no relationship between the variation in the number of woody stems and the variation in browsing intensity $(P=0.97)$.

Transect stem densities were autocorrelated $(P<0.05)$ at separation distances $<1800 \mathrm{~m}$ (Fig. 2a). We found stem density autocorrelation near zero across separation distances $\geq 5 \mathrm{~km}$, although scattered classes
Appalachian Mountains of Virginia, USA, summer 2014. Trend lines are loess smoothed fit of the autocorrelation values

statistically were significant. Similarly, browsing ratios were autocorrelated at separation distances $<1600 \mathrm{~m}$ (Fig. 2b), but were near zero at separation distances $\geq$ $5 \mathrm{~km}$, although scattered classes statistically were significant. There was little spatial dependence in stem counts or browsing ratios beyond the site scale (Fig. 3). Large nugget variance and small sill for both stem counts and browsing ratios suggested that spatial dependence was low across all distance classes and 


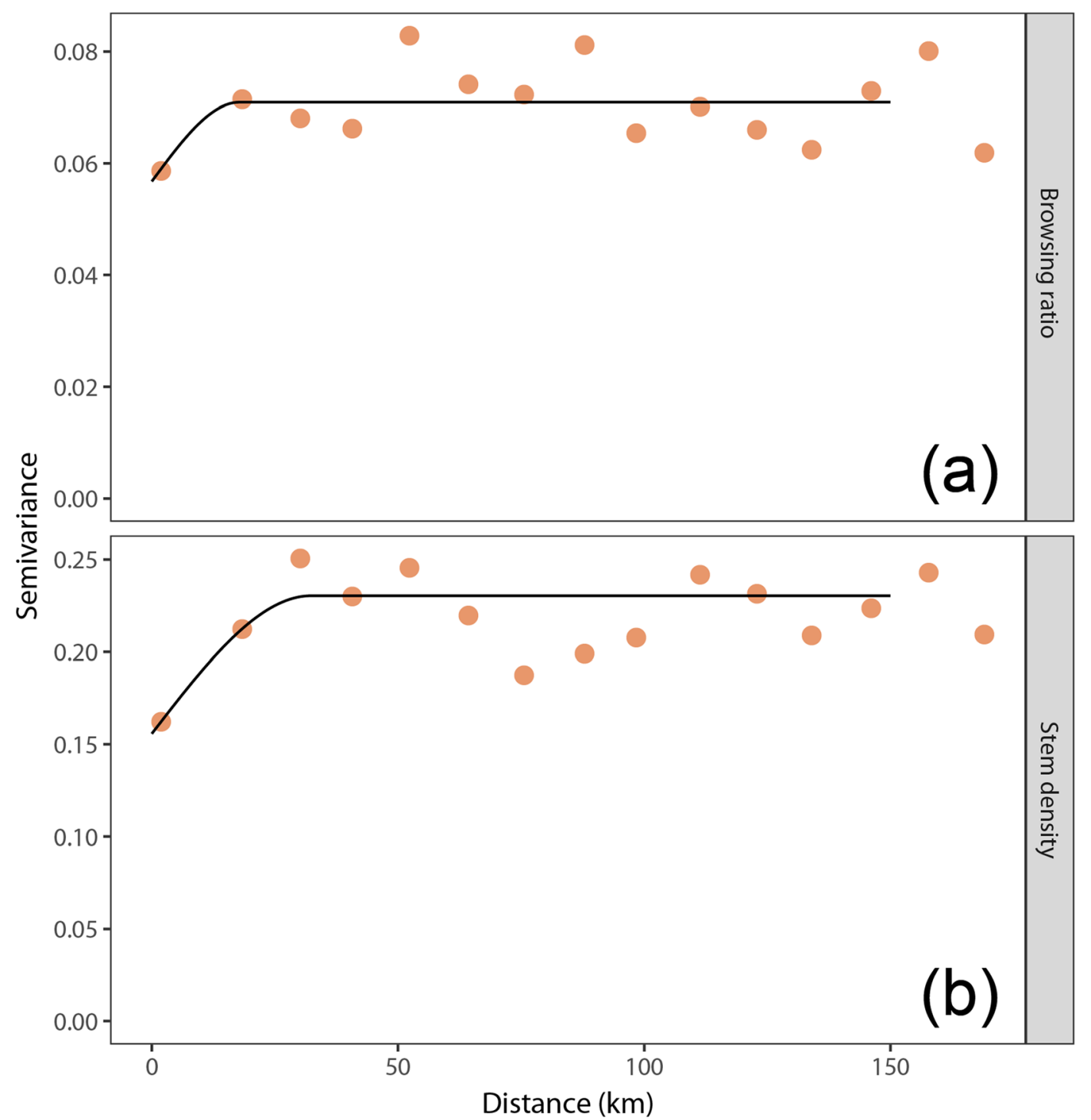

Fig. 3 Semi-variograms for woody vegetation browsing ratios (a) and stem densities (b) among transects at white-tailed deer (Odocoileus virginianus) herbivory assessment sites in the central Appalachian Mountains of Virginia, USA, summer 2014

accounted for only 32 and $21 \%$ of the variation at the shortest distance class (approximately $1900 \mathrm{~m}$ ), respectively (Table 2). There was little spatial

Table 2 Statistics for semi-variogram model fits for woody stem density and browsing ratios on white-tailed deer (Odocoileus virginianus) herbivory assessment sites in the central Appalachian Mountains of Virginia, USA, summer 2014. The proportion dependence beyond separation distances of approximately 29 and $16 \mathrm{~km}$ for stem counts and browsing ratios, respectively.

spatially structured (PSS) is the proportion of the sample variance that is explained by spatial structure (Isaaks and Srivastava 1989; Didier and Porter 2003)

\begin{tabular}{llllll}
\hline Dataset & Model & Nugget & Sill & PSS & Range (m) \\
\hline Woody density & Spherical & 0.156 & 0.229 & 0.322 & 28,913 \\
Browsing ratio & Spherical & 0.056 & 0.071 & 0.212 & 16,371 \\
\hline
\end{tabular}


Although browsing intensity and stem densities were variable across sites, on average, the mean of $\geq 3$ transects within a site was within 0.1 of the site mean browsing ratio and 0.5 stems $\mathrm{m}^{-2}$ (Fig. 4). All regions followed a similar sampling effort trend for both browsing ratios and stem densities. Accordingly, estimate accuracy was similar among regions.

\section{Discussion}

Spatial patterns of deer herbivory unexpectedly were consistent across our large study area. Herbivory patterns and the availability of woody forage generally were unchanged among physiographic regions and land use diversity classes. Contrary to our hypothesis, we

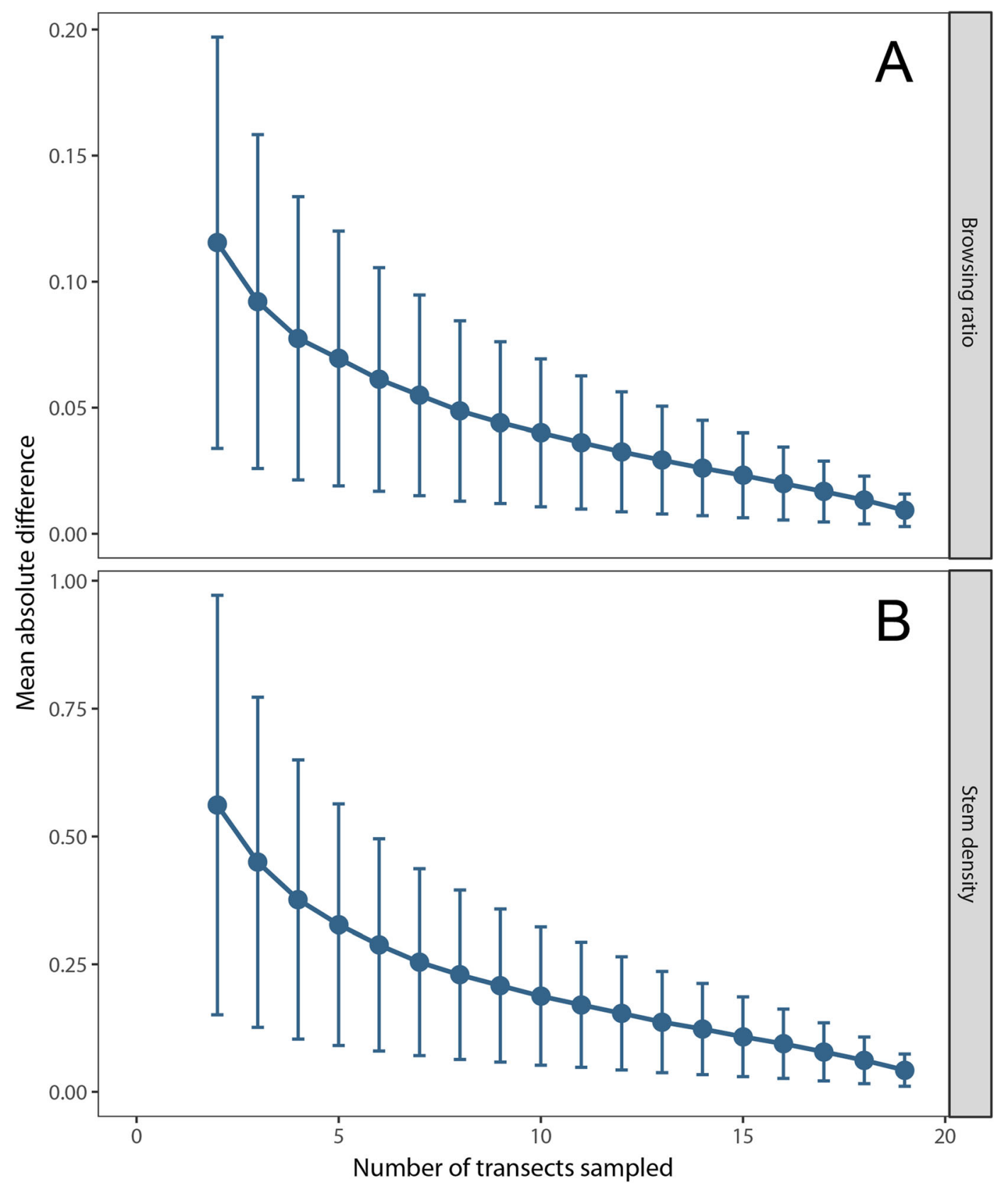

Fig. 4 Mean ( \pm SD) absolute difference of woody vegetation browsing ratios (a) or woody vegetation stem densities (b) from Monte Carlo simulations of reduced sampling on sites compared to the mean calculated from all 20 transects on white-tailed deer (Odocoileus virginianus) herbivory assessment sites in the central Appalachian Mountains, Virginia, USA, summer 2014 
found no evidence that deer in different physiographic provinces and sub-divisions or habitat conditions use different browsing strategies or display alternate herbivory patterns. Deer are highly adaptable herbivores, yet they browse selectively, choosing some vegetation species preferentially within local areas (Nixon et al. 1970; Vangilder et al. 1982; Dostaler et al. 2011). Although the availability of particular vegetation species and understory communities change substantially across the study area, deer appear to switch among available forage species in their local area to maintain a "consistent" herbivory pattern spatially which may simplify assessment protocols.

The spatially consistent herbivory patterns we observed study-wide included some relationships that do and some that do not change with scale. The total quantity (not proportion) of vegetation browsed on a site and on the transect scale were related positively to the availability of forage. For decades regionally, forage management strategies, such as forest harvesting and food plot establishment, have been used to move or concentrate deer herbivory within the landscape by creating patches of available, high-density browse in the Appalachians (e.g., Johnson et al. 1995; Campbell et al. 2004a; Miller et al. 2009; Crimmins et al. 2010). Optimal foraging theory suggests that deer may consume more vegetation at these locations if it is energetically or nutritionally beneficial (Schoener 1971; Senft et al. 1987). Our study supports the observation that deer will consume more vegetation in areas with greater amounts of browse available. Notably, our results suggest this relationship is stronger where the available browse is a type preferred by deer. As a result, how vegetation succession could develop over time under the anticipated herbivory intensity may provide additional considerations relative to management goals and habitat needs of deer and other wildlife (Johnson et al. 1995; Belote et al. 2012).

The proportion of stems browsed suggests an alternate and scale-dependent relationship with stem density. Although the proportion of stems browsed decreased as stem density increased at both the site and transect scales, this was true only when all stems were considered equally as seen elsewhere in the central Appalachians (Campbell et al. 2006). Where stem densities were weighted for deer preference, the browsing ratio had no relationship with stem density at the site scale and increased with density at the transect scale. This highlights the scale-dependent and selective nature of deer browsing and the complexity of evaluating herbivory impacts (Ford et al. 1993). Our data are consistent with the supposition that increasing forage availability would result in a smaller proportion of the vegetation browsed in general (Johnson et al. 1995; Crimmins et al. 2010). However, when the forage preference of deer also is considered, our data suggest that increasing the density of a preferred browse species would not necessarily reduce the proportion of that species consumed on a site and actually may lead to an increase of the proportion browsed at smaller scales. As a result, attempts to reduce browsing rates on a preferred browse species by increasing its availability may not be viable without careful consideration of the relationship between herbivory of the browse species and the local to perhaps the county-level deer density.

Intra-site spatial browsing uniformity was consistent across the study area. For example, intra-site variation in browsing intensity did not change across land use diversity classes. This is in contrast to our hypothesis that sites with more uniform habitats are browsed more uniformly than sites with diverse habitats and land use classes. Secondly, we found no relationship between deer browsing intensity variation and stem density variation. That is, patchy distribution of stems did not result in patchy distribution of browsing. This reflects small-scale browsing selectivity by deer suggesting that there may not be a correlation between factors that affect browsing variation and those that affect the variation in stem densities. Because there is a strong relationship between site browsing variation and browsing intensity, our data suggest that the spatial pattern of deer herbivory may be associated more directly with the relative deer population density than environmental or vegetative conditions as noted by others (deCalesta and Stout 1997; Augustine et al. 1998; Royo et al. 2010a; Royo et al. 2010b).

Deer herbivory has direct effects on particular vegetation species, forest communities, and understories, and indirect effects on many other plants and organisms (Augustine and Frelich 1998; Russell et al. 2001; Rooney and Waller 2003; Côté et al. 2004; Koh et al. 2010). The spatial patterns of herbivory observed in our study suggest that these effects require consideration of spatial context to be understood fully. Deer are spatially as well as vegetatively selective browsers, but observations and assessments are scale-dependent, reflecting in part deer biology in addition to habitat conditions. Koda and Fujita (2011) found that there is a nonlinear relationship between deer density and herbivory of forest vegetation, a result of switching diet and browse species 
at different population densities. That is, deer may exhibit density-dependent forage selectivity such that lesspreferred food being consumed at greater rates due to availability at that moment of consumption or because interactions with conspecifics alter how and where deer forage. Our data suggest that preferred browse species would not escape herbivory by deer even in areas with ample quantities of alternate browse. Frerker et al. (2013) found that browsing ratios provide reliable indices of ungulate impacts in the Great Lakes region; however, our data suggest conservation of particular plant species may need special, direct attention where deer are present. Despite these complexities and although our study does not examine causal factors, the spatial uniformity of browsing in areas with low stem densities found in our study posits a mechanism to explain the herbivory pattern whereby areas become steady-state, species depauperate "deer savannas" or "fern parks" (Stromayer and Warren 1997; Augustine et al. 1998; Rooney 2001).

There is ample evidence that vegetation in areas that experience high levels of browsing intensity over long periods can be altered significantly, reducing plant diversity (Stromayer and Warren 1997; Côté et al. 2004; Royo et al. 2010b). Because of this and because deer are spatially selective browsers, management seeking to preserve biodiversity must address the browsing intensity of the present deer herd regardless of the adequacy of available food sources in maintaining herd health. Vegetative communities shaped by high levels of herbivory can be slow to recover even if herbivory intensity is reduced, thereby resulting in legacy impact to biodiversity (Stromayer and Warren 1997; Augustine et al. 1998; Baiser et al. 2008; Royo et al. 2010b). As a result, deer management focused solely on maintaining deer health or herd density likely will not address preservation of biodiversity (McShea 2012).

\section{Conclusion}

Our results have several implications for deer herbivory impact assessments and understanding and applying them to deer management. First, our results provide one of the first examinations of the spatial variability of deer herbivory across landscapes. Particularly, our results reflect a landscape more complex in topography and associated spatial variability in vegetation communities not present in many other studies of deer herbivory (e.g., Augustine and Frelich 1998; Castleberry et al. 1999; Horsley et al. 2003; Wiegmann and Waller 2006; Goetsch et al. 2011). With improved spatial information, managers have improved capacity to assess the usefulness of available herbivory metrics based on the management scale at question, which for managing deer harvest in the Appalachian Mountains of Virginia, as well as surrounding states, occurs at the county to subregion level. Understanding both the management scale and the variability of herbivory can inform decisions on sampling intensity needed at the local to county-level to meet management needs and goals. Managers increasingly are called upon to manage holistically for biodiversity and ecosystems rather than one or a few species. By employing an informed, multi-scale approach to the assessment and understanding of deer herbivory and resulting environmental effects, managers will have improved ability to manage for the diverse desires of stakeholders, such as hunters who desire more deer versus foresters or agriculturalists who desire fewer deer.

Acknowledgments We thank the Virginia Department of Game and Inland Fisheries for sponsoring this project using funds provided from the U.S. Fish and Wildlife Service through the Wildlife and Sport Fish Restoration Program, project WE99. Specifically we thank N. Lafon, M. Knox, J. Bowman, and D. Steffen for their comments and support. We also thank J. Parkhurst and M. Cherry for their comments on this manuscript and C. Parker for his help with field data collection.

\section{References}

Augustine, D. J., \& Frelich, L. E. (1998). Effects of white-tailed deer on populations of an understory forb in fragmented deciduous forests. Conservation Biology, 12(5), 995-1004.

Augustine, D. J., \& Jordan, P. A. (1998). Predictors of white-tailed deer grazing intensity in fragmented deciduous forests. Journal of Wildlife Management, 62(3), 1076-1085.

Augustine, D. J., Frelich, L. E., \& Jordan, P. A. (1998). Evidence for two alternate stable states in an ungulate grazing system. Ecological Applications, 8(4), 1260-1269.

Baiser, B., Lockwood, J. L., La Puma, D., \& Aronson, M. F. J. (2008). A perfect storm: two ecosystem engineers interact to degrade deciduous forests of New Jersey. Biological Invasions, 10(6), 785-795.

Belote, R. T., Jones, R. H., \& Wieboldt, T. F. (2012). Compositional stability and diversity of vascular plant communities following logging disturbance in Appalachian forests. Ecological Applications, 22(2), 502-516.

Berteaux, D., Crete, M., Huot, J., Maltais, J., \& Ouellet, J. P. (1998). Food choice by white-tailed deer in relation to protein 
and energy content of the diet: a field experiment. Oecologia, 115(1-2), 84-92.

Bolker, B. M., Brooks, M. E., Clark, C. J., Geange, S. W., Poulsen, J. R., Stevens, M. H. H., \& White, J.-S. S. (2009). Generalized linear mixed models: a practical guide for ecology and evolution. Trends in Ecology \& Evolution, 24(3), $127-135$.

Bressette, J. W., Beck, H., \& Beauchamp, V. B. (2012). Beyond the browse line: complex cascade effects mediated by whitetailed deer. Oikos, 121(11), 1749-1760.

Campbell, T. A., Laseter, B. R., Ford, W. M., \& Miller, K. V. (2004a). Movements of female white-tailed deer (Odocoileus virginianus) in relation to timber harvests in the central Appalachians. Forest Ecology and Management, 199(2), 371-378.

Campbell, T. A., Laseter, B. R., Ford, W. M., \& Miller, K. V. (2004b). Feasibility of localized management to control white-tailed deer in forest regeneration areas. Wildlife Society Bulletin, 32(4), 1124-1131.

Campbell, T. A., Laseter, B. R., Ford, W. M., Odom, R. H., \& Miller, K. V. (2006). Abiotic factors influencing deer browsing in West Virginia. Northern Journal of Applied Forestry, 23(1), 20-26.

Castleberry, S. B., Ford, W. M., Miller, K. V., \& Smith, W. P. (1999). White-tailed deer browse preferences in a southern bottomland hardwood forest. Southern Journal of Applied Forestry, 23(2), 78-82.

Chollet, S., Baltzinger, C., Ostermann, L., Saint-Andre, F., \& Martin, J. L. (2013). Importance for forest plant communities of refuges protecting from deer browsing. Forest Ecology and Management, 289(2013), 470-477.

Clinton, B. D. (2003). Light, temperature, and soil moisture responses to elevation, evergreen understory, and small canopy gaps in the southern Appalachians. Forest Ecology and Management, 186(1-3), 243-255.

Comisky, L., Royo, A. A., \& Carson, W. P. (2005). Deer browsing creates rock refugia gardens on large boulders in the Allegheny National Forest, Pennsylvania. American Midland Naturalist, 154(1), 201-206.

Côté, S. D., Rooney, T. P., Tremblay, J.-P., Dussault, C., \& Waller, D. M. (2004). Ecological impacts of deer overabundance. Annual Review of Ecology, Evolution, and Systematics, 35(2004), 113-147.

Crimmins, S. M., Edwards, J. W., Ford, W. M., Keyser, P. D., \& Crum, J. M. (2010). Browsing patterns of white-tailed deer following increased timber harvest and a decline in population density. International Journal of Forestry Research, 20107, 1-7.

de Calesta, D. S., \& Stout, S. L. (1997). Relative deer density and sustainability: a conceptual framework for integrating deer management with ecosystem management. Wildlife Society Bulletin, 25(2), 252-258.

De Reu, J., Bourgeois, J., Bats, M., Zwertvaegher, A., Gelorini, V., De Smedt, P., Chu, W., Antrop, M., De Maeyer, P., Finke, P., Van Meirvenne, M., Verniers, J., \& Crombé, P. (2013). Application of the topographic position index to heterogeneous landscapes. Geomorphology, 186(0), 39-49.

Didier, K. A., \& Porter, W. F. (2003). Relating spatial patterns of sugar maple reproductive success and relative deer density in northern New York State. Forest Ecology and Management, 181(1-2), 253-266.
Dostaler, S., Ouellet, J. P., Therrien, J. F., \& Côté, S. D. (2011). Are feeding preferences of white-tailed deer related to plant constituents? Journal of Wildlife Management, 75(4), 913-918.

Fenneman, N. M. (1938). Physiography of eastern United States. New York: McGraw-Hill.

Ford, W. M., Johnson, A. S., Hale, P. E., \& Wentworth, J. M. (1993). Availability and use of spring and summer woody browse by deer in clearcut and uncut forests of the southern Appalachians. Southern Journal of Applied Forestry, 17(3), 116-119.

Ford, W. M., Odom, R. H., Hale, P. E., \& Chapman, B. R. (2000). Stand-age, stand characteristics, and landform effects on understory herbaceous communities in southern Appalachian cove-hardwoods. Biological Conservation, 93(2), 237-246.

Fortin, M.-J., and M. R. T. Dale. (2009). Spatial autocorrelation. Pages 89-103 in A. S. Fotheringham, and P. A. Rogerson, Eds. Spatial Analysis. (pp. 89-103). London, England: SAGE Publications.

Frerker, K., Sonnier, G., \& Waller, D. M. (2013). Browsing rates and ratios provide reliable indices of ungulate impacts on forest plant communities. Forest Ecology and Management, 291(0), 55-64.

Fry, J. A., G. Xian, S. Jin, J. A. Dewitz, C. G. Homer, L. Yang, C. A. Barnes, N. D. Herold, and J. D. Wickham. (2011). Completion of the 2006 national land cover database for the conterminous United States. Photogrammetric Engineering \& Remote Sensing 77(9), 858-864.

Gawler, S. C. (2008). Northeastern terrestrial wildlife habitat classification. Report to the Virginia Department of Game and Inland Fisheries on behalf of the Northeast Association of Fish and Wildlife Agencies and the National Fish and Wildlife Foundation.

Goetsch, C., Wigg, J., Royo, A. A., Ristau, T., \& Carson, W. P. (2011). Chronic over browsing and biodiversity collapse in a forest understory in Pennsylvania: results from a 60 year-old deer exclusion plot. Journal of the Torrey Botanical Society, 138(2), 220-224.

Halls, L. K. (1984). White-tailed deer: Ecology and management. Harrisburg, Pennsylvania: Stackpole Books.

Hobbs, N. T. (1996). Modification of ecosystems by ungulates. Journal of Wildlife Management, 60(4), 695-713.

Horsley, S. B., Stout, S. L., \& DeCalesta, D. S. (2003). Whitetailed deer impact on the vegetation dynamics of a northern hardwood forest. Ecological Applications, 13(1), 98-118.

Isaaks, E. H., \& Srivastava, R. M. (1989). An introduction to applied geostatistics. Oxford: Oxford University Press.

Johnson, A. S., Hale, P. E., Ford, W. M., Wentworth, J. M., French, J. R., Anderson, O. F., \& Pullen, G. B. (1995). White-tailed deer foraging in relation to successional stage, overstory type and management of southern Appalachian forests. American Midland Naturalist, 133(1), 18-35.

Kniowski, A. B., \& Ford, W. M. (2017). Predicting intensity of white-tailed deer herbivory in the Central Appalachian Mountains. Journal of Forestry Research. https://doi. org/10.1007/s11676-017-0476-6.

Koda, R., \& Fujita, N. (2011). Is deer herbivory directly proportional to deer population density? Comparison of deer feeding frequencies among six forests with different deer density. Forest Ecology and Management, 262(3), 432-439. 
Koh, S., Bazely, D. R., Tanentzap, A. J., Voigt, D. R., \& Da Silva, E. (2010). Trillium grandiflorum height is an indicator of white-tailed deer density at local and regional scales. Forest Ecology and Management, 259(8), 1472-1479.

Krueger, L. M., \& Peterson, C. J. (2006). Effects of white-tailed deer on Tsuga canadensis regeneration: evidence of microsites as refugia from browsing. American Midland Naturalist, 156(2), 353-362.

McNab, W. H. (1993). A topographic index to quantify the effect of mesoscale landform on site productivity. Canadian Journal of Forest Research, 23(6), 1100-1107.

McShea, W. J. (2012). Ecology and management of white-tailed deer in a changing world. Annals of the New York Academy of Sciences, 1249(1), 45-56.

Meilleur, A., Bouchard, A., \& Bergeron, Y. (1994). The relation between geomorphology and forest community types of the Haut-Saint-Laurent, Quebec. Vegetatio, 111(2), 173-192.

Miller, B. F., Campbell, T. A., Laseter, B. R., Ford, W. M., \& Miller, K. V. (2009). White-tailed deer herbivory and timber harvesting rates: implications for regeneration success. Forest Ecology and Management, 258(7), 1067-1072.

Morellet, N., Champely, S., Gaillard, J.-M., Ballon, P., \& Boscardin, Y. (2001). The browsing index: new tool uses browsing pressure to monitor deer populations. Wildlife Society Bulletin, 29(4), 1243-1252.

Morellet, N., Gaillard, J.-M., Hewison, A. J. M., Ballon, P., Boscardin, Y., Duncan, P., Klein, F., \& Maillard, D. (2007). Indicators of ecological change: new tools for managing populations of large herbivores. Journal of Applied Ecology, 44(3), 634-643.

Nakagawa, S., \& Schielzeth, H. (2013). A general and simple method for obtaining R2 from generalized linear mixedeffects models. Methods in Ecology and Evolution, 4(2), 133-142.

Nixon, C. M., McClain, M. W., \& Russell, K. R. (1970). Deer food habits and range characteristics in Ohio. Journal of Wildlife Management, 34(4), 870-886.

Oliphant, A. J., Wynne, R. H., Zipper, C. E., Ford, W. M., Donovan, P. F., Li, J. (2016). Autumn olive (Elaeagnus umbellata) presence and proliferation on former surface coal mines in Eastern USA. Biological Invasions, 19(1), 179-195.

Rearick, D., Kintz, L., Burke, K. L., \& Ransom, T. S. (2011). Effects of white-tailed deer on the native earthworm, Eisenoides carolinensis, in the southern Appalachian Mountains, USA. Pedobiologia, 54, S173-S180.

Rooney, T. P. (1997). Escaping herbivory: refuge effects on the morphology and shoot demography of the clonal forest herb Maianthemum canadense. Journal of the Torrey Botanical Society, 124(4), 280-285.

Rooney, T. P. (2001). Deer impacts on forest ecosystems: a North American perspective. Forestry, 74(3), 201-208.

Rooney, T. P., \& Waller, D. M. (2003). Direct and indirect effects of white-tailed deer in forest ecosystems. Forest Ecology and Management, 181(1-2), 165-176.

Royo, A. A., Collins, R., Adams, M. B., Kirschbaum, C., \& Carson, W. P. (2010a). Pervasive interactions between ungulate browsers and disturbance regimes promote temperate forest herbaceous diversity. Ecology, 91(1), 93-105.
Royo, A. A., Stout, S. L., deCalesta, D. S., \& Pierson, T. G. (2010b). Restoring forest herb communities through landscape-level deer herd reductions: is recovery limited by legacy effects? Biological Conservation, 143(11), 2425-2434.

Russell, F. L., Zippin, D. B., \& Fowler, N. L. (2001). Effects of white-tailed deer (Odocoileus virginianus) on plants, plant populations and communities: a review. American Midland Naturalist, 146(1), 1-26.

Schmitz, O. J. (1991). Thermal constraints and optimization of winter feeding and habitat choice in white-tailed deer. Holarctic Ecology, 14(2), 104-111.

Schoener, T. W. (1971). Theory of feeding strategies. Annual Review of Ecology and Systematics, 2, 2369-2404.

Senft, R. L., Coughenour, M. B., Bailey, D. W., Rittenhouse, L. R., Sala, O. E., \& Swift, D. M. (1987). Large herbivore foraging and ecological hierarchies. Bioscience, 37(11), 789-799.

Stevens, D. L. J., \& Olsen, A. R. (2004). Spatially balanced sampling of natural resources. Journal of the American Statistical Association, 99(465), 262-278.

Stromayer, K. A. K., \& Warren, R. J. (1997). Are overabundant deer herds in the eastern United States creating alternate stable states in forest plant communities? Wildlife Society Bulletin, 25(2), 227-234.

Swanson, F. J., Kratz, T. K., Caine, N., \& Woodmansee, R. G. (1988). Landform effects on ecosystem patterns and processes. Bioscience, 38(2), 92-98.

Tierney, G. L., Faber-Langendoen, D., Mitchell, B. R., Shriver, W. G., \& Gibbs, J. P. (2009). Monitoring and evaluating the ecological integrity of forest ecosystems. Frontiers in Ecology and the Environment, 7(6), 308-316.

Tierson, W. C., Mattfeld, G. F., Sage, R. W., \& Behrend, D. F. (1985). Seasonal movements and home ranges of whitetailed deer in the Adirondacks. Journal of Wildlife Management, 49(3), 760-769.

Turner, M. G. (1989). Landscape ecology: the effect of pattern on process. Annual Review of Ecology and Systematics, 20, 20171-20197.

Urban, D. L., O'Neill, R. V., \& Shugart, H. H. (1987). Landscape ecology. Bioscience, 37(2), 119-127.

Vangilder, L. D., Torgerson, O., \& Porath, W. R. (1982). Factors influencing diet selection by white-tailed deer. Journal of Wildlife Management, 46(3), 711-718.

Virginia Department of Game and Inland Fisheries. (2015). Virginia deer management plan 2015-2024. Virginia: Richmond.

Wiegmann, S. M., \& Waller, D. M. (2006). Fifty years of change in northern upland forest understories: identity and traits of "winner" and "loser" plant species. Biological Conservation, 129(1), 109-123.

Wilson, J. P., \& Gallant, J. C. (Eds.). (2000). Terrain analysis: principles and applications. New York: Wiley.

Zar, J. H. (1984). Biostatistical analysis. Englewood Cliffs, New Jersey: Prentice-Hall, Inc..

Zuur, A. F., Ieno, E. N., Walker, N. J., Saveliev, A. A., \& Smith, G. M. (2009). Mixed effects models and extensions in ecology with $R$. New York: Springer. 